\title{
Pengaruh Model Project Based Learning (PjBL) Terhadap Kemampuan Berpikir Tingkat Tinggi Ditinjau dari Motivasi Berprestasi Siswa Kelas IV Sekolah Dasar
}

\author{
Hikmatul Fitri $^{(1)}$, I Wayan Dasna ${ }^{(2)}$, Suharjo ${ }^{(3)}$ \\ ${ }^{1,2,3}$ Pendidikan Dasar, Pascasarjana-Universitas Negeri Malang \\ Email: ${ }^{1}$ hikmatulf394@gmail.com, ${ }^{2}$ idasna@um.ac.id, ${ }^{3}$ suharjofip@gmail.com
}

\section{Tersedia Online di \\ http://www.jurnal.unublitar.ac.id/ index.php/briliant}

\begin{tabular}{l}
\hline Sejarah Artikel \\
\hline Diterima pada 27 April 2018 \\
Disetuji pada 29 April 2018 \\
Dipublikasikan pada 13 Mei \\
2018 Hal. 201-212 \\
\hline
\end{tabular}

\section{Kata Kunci:}

project based learning (pjbl), kemampuan berpikir tingkat tinggi, motivasi berprestasi, siswa sekolah dasar

\section{DOI:}

http://dx.doi.org/10.28926/briliant .v3i2.187

\begin{abstract}
Abstrak: Penelitian ini bertujuan untuk mengetahui perbedaan kemampuan berpikir tingkat tinggi antara siswa yang dibelajarkan dengan model project based learning (PjBL) dan siswa yang dibelajarkan dengan model konvensional yang ditinjau dari motivasi berprestasi. Penelitian ini merupakan quasi eksperiment dengan rancangan non equivalent control group. Data penelitian dikumpulkan dengan mengunakan instrumen tes kemampuan berpikir tingkat tinggi dan angket motivasi berprestasi. Hasil penelitian menunjukkan bahwa, (1) ada pengaruh yang signifikan model PjBL terhadap kemampuan berpikir tingkat tinggi, (2) ada pengaruh motivasi berprestasi terhadap kemampuan berpikir tingkat tinggi, dan (3) model $\mathrm{PjBL}$ dan motivasi berprestasi yang secara bersama-sama berpengaruh terhadap kemampuan berpikir tingkat tinggi.
\end{abstract}

Keberhasilan implementasi kurikulum 2013 dalam mencetak generasi yang unggul tidak terlepas dari adanya peningkatan pembelajaran yang berpusat pada siswa. Upaya peningkatan pembelajaran pada kurikulum 2013 yaitu dengan melaksanakan kegiatan pembelajaran menggunakan pendekatan saintifik (Fuadah, 2017). Hal tersebut sejalan dengan dasar pemikiran dalam panduan teknis kurikulum 2013 yang menyatakan bahwa strategi pelaksanaan kegiatan belajar siswa sekolah dasar yang dikehendaki kurikulum 2013 yakni melalui pendekatan saintifik/ilmiah. Menurut Hosnan (2014) pendeketan saintifik adalah proses belajar yang dilaksanakan dengan kegiatan ilmiah yang memuat keterampilan mengamati, menanya, mencoba, menalar dan mengkomunikasikan. Serangkaian kegiatan tersebut biasa disebut dengan 5M.

Pelaksanaan proses pembelajaran menggunakan pendekatan saintifik hendaknya dapat mengembangkan keterampilan berpikir siswa. Menurut Greenstein (2012) bahwa keterampilan berpikir yang dibutuhkan pada abad 21 mencakup berpikir kritis, pemecahan masalah, kreativitas, dan metakoginitif. Salah satu hal penting yang perlu dicermati dalam proses pembelajaran di kelas yaitu mengasah kemampuan siswa berupa keterampilan berpikir tingkat tinggi atau high order thinking skills (HOTS), dengan tujuan meningkatkan kemampuan siswa berpikir menalar untuk menjawab pertanyaan-pertanyaan atau memecahkan suatu kasus/masalah yang lebih rumit. Berpikir tingkat tinggi merupakan suatu 
aktivitas berpikir siswa yang melibatkan level kognitif hierarki tingkat tinggi dari taksonomi berpikir Bloom, yang meliputi menganalisis (analyzing), mengevaluasi (evaluating), dan mengkreasi (creating) Anderson \& Krathwohl (2015).

Suatu masalah dalam pembelajaran saintifik di sekolah dasar yakni lemahnya pelaksanaan pembelajaran yang mampu mengembangkan kemampuan berpikir siswa (Susanto, 2013). Berdasarkan hasil observasi yang dilakukan pada tanggal 4-5 Oktober 2017 di kelas IV pada salah satu Sekolah Dasar Kabupaten Jombang menunjukkan selama proses belajar mengajar guru dan siswa melakukan tanya jawab dengan mengajukan pertanyaan tertutup seperti sebutkan!, pilihlah! tunjukkan!. Kegiatan dengan pertanyaan maupun perintah tersebut cenderung kurang mengaktifkan siswa dalam berpikir menalar, menganalisis, dan mengevaluasi informasi dan pengetahuan. Pelaksanaan proses pembelajaran yang berlangsung di kelas hanya diarahkan pada kemampuan siswa untuk menghafal informasi, otak siswa dipaksa hanya untuk mengingat dan menimbun berbagai informasi tanpa dituntut untuk memahami informasi yang diperoleh untuk menghubungkannya dengan situasi dalam kehidupan sehari-hari. Hal tersebut menunjukkan bahwa selama ini masih banyak siswa yang masih dilatih pada kemampuan berpikir tingkat rendah atau low order thinking (LOT). Sejalan dengan Tembang (2017) aktivitas di kelas yang didominasi penugasan dan hafalan menunjukkan bahwa rendahnya keterlibatan kemampuan berpikir siswa di dalam pembelajaran.

Meningkatkan keterampilan berpikir tingkat tinggi tidak hanya berpusat pada siswa saja, akan tetapi juga dipengaruhi oleh pemahaman dan strategi guru selama pembelajaran (Yusmanto, 2017). Kamin (2016) menyatakan bahwa Higher order thinking (HOTS) should be an integral part of teaching and learning, thinking skills lessons should be part of curriculum. Oleh karena itu strategi guru sangat penting dalam menghubungkan keterampilan beripikir siswa selama pembelajaran di kelas (Noor, 2009). Guru harus memiliki pemahaman yang cukup akan mengembangkan keterampilan berpikir ini, agar mampu merancang strategi yang tepat untuk membiasakan siswa berpikir tingkat tinggi.

Higher order thiking skills (HOTS) dapat tercapai ketika siswa secara aktif dalam memahami dan memadukan pengetahuan dengan pengalaman mereka (Anderson \& Krathwohl, 2015). Sejalan dengan hal itu Deluca (2011) menyatakan bahwa untuk mengembangkan kemampuan berpikir tingkat tinggi siswa harus terlebih dahulu memahami pengetahuan faktual, konseptual, dan prosedural menerapkan pengetahuan mereka untuk belajar dengan melakukan dan kemudian merenungkan proses yang menghasilkan sebuah solusi. Guru dapat melakukannya dengan membimbing siswa melalui aktivitas pengamatan, pembentukan konsep, pemberian respon, menganalisa, membandingkan dan memberikan pertimbangan yang dibutuhkan. Keaktifan siswa dan bimbingan guru sangat berkontribusi selama pembelajaran (Zerihun et. al, 2012). Proses pembelajaran tersebut dapat dilakukan apabila guru mampu mempersiapkan serangkaian aktivitas dengan baik dan terencana.

Salah satu model pembelajaran yang sesuai dengan karakteriktik saintifik dan berpikir tingkat tinggi adalah model Project Based Learning (PjBL). Sejalan dengan hal tersebut Zubaidah (2017) menyatakan bahwa pembelajaran berbasis proyek adalah model yang ideal untuk memenuhi tujuan pendidikan abad ke-21, karena melibatkan prinsip 4C yaitu berpikir kritis, komunikasi, kolaborasi dan 
kreativitas. Model PjBL dapat mengkaitkan kemampuan berpikir berpikir tingkat tinggi siswa (Hayati, 2016). Langkah-langkah (sintaks) pembelajaran berbasis proyek sebagaimana yang dikembangkan oleh The George Lucas Educational Foundation (2005) terdiri atas, (1) mengajukan pertanyaan esensial kepada siswa, (2) mendesain rencana proyek, (3) menyusun jadwal kegiatan, (4) memonitoring aktivitas siswa, (5) menilai keberhasilan siswa, dan (6) mengevaluasi pngalaman siswa.

Pelaksanaan pembelajaran menggunakan model PjBL tidak akan berjalan baik apabila siswa memiliki motivasi berprestasi yang rendah (Sani 2014). Motivasi berprestasi merupakan kebutuhan untuk melakukan dengan baik atau berjuang untuk sukses, lalu dibuktikan dengan ketekunan dan usaha dalam menghadapi kesulitan (Singh, 2011). Dengan kata lain seorang siswa memiliki motivasi berprestasi yang tinggi dapat ditunjukkan dengan mereka akan berusaha lebih keras untuk berhasil dalam proses pembelajaran.

Berdasarkan penelitian Grand (dalam Hayati, 2016) pembelajaran berbasis proyek ini dapat: (1) mengembangkan intellegences, (2) meningkatkan sistem pengetahuan, domain pengetahuan, dan metakognisi pengetahuan. Hasil penelitian Hayati (2016) menunjukkan tingkat efektivitas worksheet berbasis Project Based Learning (PjBL) dalam menumbuhkan kemampuan berpikir siswa setelah pembelajaran sebesar 58\% memiliki kualifikasi berpikir tingkat tinggi yang baik. Hasil penelitian Anjarini (2017) menunjukkan bahwa model PjBL berbasis outdoor study berpengaruh signifikan terhadap kemampuan berpikir dan kemampuan menyusun karya ilmiah. Hasil penelitian Maula (2014) menunjukkan bahwa penerapan model PjBL berpengaruh terhadap kemampan berpikir kreatif dan hasil belajar siswa kelas VII di SMP Negeri 2 Balung.

Hasil penelitian Sanderayanti dkk (2015) menunjukkan bahwa antara variabel motivasi berprestasi dan kemampuan berpikir kritis baik secara bersamasama maupun secara terpisah memiliki pengaruh positif terhadap kemampuan berpikir kritis pelajaran matematika di sekolah dasar. Hasil penelitian Setyorini dkk (2015) menunjukkan bahwa ada perbedaan motivasi belajar antara siswa yang dibelajarkan dengan strategi inkuiri terbimbing dengan siswa yang dibelajarkan dengan strategi pembelajaran ekspositori.

Beberapa penelitian tersebut telah membahas pengaruh model pembelajaran dan motivasi berprestasi, namun hasil penelitian belum menjelaskan secara khusus tentang pengaruh model project based learning ( $\mathrm{PjBL}$ ) dan motivasi berprestasi terhadap kemampuan berpikir tingkat tinggi siswa khususnya di Sekolah Dasar. Sehingga sangat perlu dilakukan penelitian tentang pengaruh model project based learning (PjBL) terhadap kemampuan berpikir tingkat tinggi ditinjau dari motivasi berprestasis siswa kelas IV Sekolah Dasar.

Guna merespon ide tersebut, maka diperlukan tindakan suatu penelitian. Penelitian ini bertujuan untuk, (1) mengetahui pengaruh yang siginifikan penerapan model PjBL terhadap kamampuan berpikir tingkat tinggi, (2) mengetahui pengaruh yang signifikan motivasi berprestasi terhadap kemampuan berpikir tingkat tinggi, dan (3) mengetahui penerapan model PjBL dan motivasi berprestasi secara bersama-sama berpengaruh terhadap kemampuan berpikir tingkat tinggi siswa. 


\section{METODE}

Metode penelitian yang digunakan adalah penelitian eksperimen dengan jenis penelitian quasi experiment. Desain penelitian yang digunakan yaitu Non Equivalent Control Group. Populasi penelitian yaitu siswa kelas IV A dan IV C semester 2 di SD Plus Darul Ulum Kabupaten Jombang tahun pelajaran 2017/2018 dengan jumlah keseluruhan sebanyak 44 siswa. Penentuan kelas menggunakan teknik Cluster Random Sampling. Adapun kelas IV A populasi sebanyak 21 siswa sebagai kelas kontrol yang dibelajarkan menggunakan model konvensional (ceramah, diskusi) dan kelas IV C dengan populasi sebanyak 23 siswa sebagai kelas eksperimen yang dibelajarkan menggunakan model PjBL.

Variabel dalam penelitian ini yaitu, (1) model project based learning (PjBL) sebagai variabel independent (bebas), (2) kemampuan berpikir tingkat tinggi sebagai variabel terikat (dependent), dan (3) motivasi berprestasi sebagai variabel moderasi. Instrumen yang digunakan untuk mengumpulkan data yaitu berupa tes kemampuan berpikir tingkat tinggi dan angket motivasi berprestasi yang sebelumnya sudah di validasi konstruk pada dosen dan guru selain itu juga telah divalidasi empirik pada siswa lain sehingga butir soal sudah dapat dikatakan valid dan reliabel.

Penelitian ini menggunakan metode analisis deskriptif statistik dan analisis multivariat. Uji hipotesis dilakukan dengan Two Way Analisis of Variat (two way ANAVA) dengan bantuan SPSS 21.0 for Windows. Sebelum melakukan analisis data dan uji hipotesis, data yang diperoleh perlu diuji asumsinya terlebih dahulu yang dilakukan dengan uji normalitas dan homogenitas varians.

\section{HASIL}

Keefektifan model pembelajaran dapat diketahui dari hasil rata-rata nilai kemampuan berpikir tingkat tinggi. Selisih yang diperoleh setelah setiap variabel sudah diketahui perbedaan rata-rata antara nilai posttest dan pretest kemampuan berpikir tingkat tinggi berdasarkan model pembelajaran dan motivasi berprestasi yang berbeda. Perbedaan rata-rata tersebut diasumsikan sebagai pengaruh keefektian model pembelajaran yang diterapkan ditinjau dari tinggi rendahnya motivasi berprestasi siswa. Selisih berdasarkan model pembelajaran dan motivasi berprestasi siswa dapat dilihat pada Tabel 1.

Tabel 1. Rata-rata Siswa Berdasarkan Model Pembelajaran dan Motivasi Berprestasi

\begin{tabular}{lcccccc}
\hline \multirow{2}{*}{$\begin{array}{c}\text { Motivasi } \\
\text { Berprestasi }\end{array}$} & \multicolumn{4}{c}{$\begin{array}{c}\text { Rembelajaratan Konvensional } \\
\text { (Kelas Kontrol) }\end{array}$} & $\begin{array}{c}\text { Siswa } \\
\text { Pembelajaran PjBL } \\
\text { (Kelas Eksperimen) }\end{array}$ \\
\cline { 2 - 7 } & Pretest & Posttest & Selisih & Pretest & Posttest & Selisih \\
\hline Motivasi Rendah & 55,00 & 81,25 & 26,25 & 60,00 & 87,14 & 27,14 \\
Motivasi Tinggi & 44,00 & 86,00 & 42,00 & 44,44 & 88,89 & 44,45 \\
\hline Total & 55,71 & 82,85 & 27,14 & 50,86 & 84,34 & 33,47 \\
\hline
\end{tabular}

Dapat diketahui bahwa kelas eksperimen mempunyai selisih rata-rata sebesar 33,47, sedangkan pada kelas kontrol hanya sebesar 27,14. Hal tersebut menunjukkan bahwa peningkatan rata-rata nilai siswa pada kelas eksperimen lebih 
besar dibandingkan dengan kelas kontrol. Hasil rata-rata pada tabel di atas menunjukkan bahwa penerapan model project based learning ( $\mathrm{PjBL}$ ) dapat memberikan pengaruh dan keefektifan pembelajaran yang lebih besar dibandingkan dengan pembelajaran konvensional yang biasa diterapkan oleh guru.

Kelas eksperimen, menunjukkan peningkatan rata-rata nilai paling tinggi pada kelompok siswa dengan motivasi berprestasi tinggi sebesar 44,45 dibandingkan dengan kelas kontrol hanya 42,00, sedangkan pada kelompok motivasi berprestasi rendah rendah untuk kelas eksperimen diperoleh nilai sebesar 27,14 dibandingkan dengan kelas kontrol hanya 26,25. Hal tersebut menunjukkan bahwa model project based learning (PjBL) dan motivasi berprestasi mampu memberikan pengaruh yang lebih besar terhadap kemampuan berpikir tingkat tinggi siswa. Hasil analisis data anava dua jalur untuk menguji hipotesis dapat dilihat pada Tabel 2 .

Tabel 2. Hasil Two Way ANAVA

\begin{tabular}{|c|c|c|c|c|c|}
\hline \multicolumn{6}{|c|}{$\begin{array}{l}\text { Tests of Between-Subjects Effects } \\
\end{array}$} \\
\hline \multicolumn{6}{|c|}{ Dependent Variable: Hots } \\
\hline Source & $\begin{array}{l}\text { Type III Sum } \\
\text { of Squares }\end{array}$ & Df & $\begin{array}{l}\text { Mean } \\
\text { Square }\end{array}$ & $\mathrm{F}$ & Sig. \\
\hline $\begin{array}{l}\text { Corrected } \\
\text { Model }\end{array}$ & $2228.989^{\mathrm{a}}$ & 3 & 742.996 & 6.515 & .001 \\
\hline Intercept & 40521.129 & 1 & 40521.129 & 355.299 & .000 \\
\hline Model & 745.583 & 1 & 745.583 & 6.537 & .014 \\
\hline Motivasi & 984.805 & 1 & 984.805 & 8.635 & .005 \\
\hline $\begin{array}{l}\text { Model * } \\
\text { Motivasi }\end{array}$ & 714.459 & 1 & 714.459 & 6.265 & .017 \\
\hline Error & 4561.920 & 40 & 114.048 & & \\
\hline Total & 47600.000 & 44 & & & \\
\hline Corrected Total & 6790.909 & 43 & & & \\
\hline
\end{tabular}

a. $\mathrm{R}$ Squared $=.328$ (Adjusted R Squared $=.278$ )

Berdasarkan tabel di atas untuk menguji hipotesis yang pertama pada baris model menunjukkan nilai F-hitung 6,537 dengan taraf signifikansi 0,014. Hasil F-hitung yang diperoleh dibandingkan dengan F-tabel dengan $\mathrm{N}=44$ pada taraf signifikansi 5\% yaitu 4,067. Hasil F-hitung yang diperoleh lebih besar dari F-tabel $(6,537>4,067)$. Dengan demikian dapat disimpulkan bahwa $\mathrm{H}_{1}$ diterima dan $\mathrm{H}_{0}$ ditolak atau juga dapat dikatakan ada pengaruh yang signifikan model pembelajaran terhadap kemampuan berpikir tingkat tinggi siswa.

Hasil pengujian hipotesis kedua, dapat dilihat bahwa hasil perhitungan pada baris motivasi diketahui nilai F-hitung sebesar 8,635 dengan taraf signifikansi 0,005. Hasil F-hitung yang diperoleh dibandingkan dengan F-tabel dengan $\mathrm{N}=44$ pada taraf signifikansi $5 \%$ yaitu 4,067. Hasil F-hitung yang diperoleh lebih besar dari F-tabel $(8,635>4,067)$. Dengan demikian dapat disimpulkan bahwa $\mathrm{H}_{1}$ diterima dan $\mathrm{H}_{0}$ ditolak atau juga dapat dikatakan ada pengaruh yang signifikan motivasi berprestasi terhadap kemampuan berpikir tingkat tinggi siswa. 
Hasil pengujian hipotesis ketiga, dapat dilihat bahwa hasil perhitungan pada baris model*motivasi diketahui nilai F-hitung $=6,265$ dengan Signifikansi menunjukkan 0,017. Hasil F-hitung yang diperoleh dibandingkan dengan F-tabel dengan $\mathrm{N}=44$ pada taraf signifikansi 5\% yaitu 4,067. Hasil F-hitung yang diperoleh lebih besar dari F-tabel $(6,265>4,067)$. Dengan demikian dapat disimpulkan bahwa $\mathrm{H}_{1}$ diterima dan $\mathrm{H}_{0}$ ditolak atau juga dapat dikatakan ada pengaruh model pembelajaran dan motivasi berprestasi secara bersama-sama berpengaruh signifikan terhadap kemampuan berpikir tingkat tinggi siswa.

\section{PEMBAHASAN}

\section{Pengaruh Model Project Based Learning (PjBL) Terhadap Kemampuan Berpikir Tingkat Tinggi Siswa}

Berdasarkan hasil analisis data tentang pengaruh model project based learning (PjBL) terhadap kemampuan berpikir tingkat tinggi siswa dapat diketahui bahwa terdapat pengaruh yang signifikan dari penerapan model project based learning ( $\mathrm{PjBL}$ ) terhadap kemampuan berpikir tingkat tinggi. Hal ini sejalan dengan peneltian yang dilakukan Kizkapan and Bektas (2017) menyatakan bahwa terdapat pengaruh yang signifikan penerapan model project based learning (PjBL) terhadap kemampuan berpikir tingkat tinggi siswa. Hasil penelitian lain oleh Amalia (2015) menunjukkan bahwa model project based learning (PjBL) berpengaruh signifikan terhadap kemampuan berpikir tingkat tinggi pada materi suhu dan kalor. Selain itu penelitian ini didukung oleh Lopes et. al (2014) bahwa penerapan model project based learning (PjBL) dapat meningkatkan kemampuan berpikir tingkat tinggi dan problem solving siswa.

Penerapan model project based learning (PjBL) telah terbukti dapat memberikan pengaruh yang cukup besar terhadap kemampuan berpikir tingkat tinggi siswa. Hal tersebut dikarenakan pada sintaks/langkah model PjBL yang terdiri atas memunculkan suatu permasalahan awal, mendesain rencana kegiatan proyek, menjadwal kegiatan proyek, memantau pelaksanaan kegiatan proyek, penilaian hasil kegiatan proyek dan mengevaluasi pengalaman kegiatan proyek. Dalam langkah kegiatan model $\mathrm{PjBL}$ ini siswa sudah diberi rangsangan untuk mengoptimalkan kemampuan berpikir tingkat tinggi yang dimilikinya.

Indikator kemampuan berpikir tingkat tinggi menurut Bloom (dalam Anderson \& Krathwohl, 2015) meliputi kemampuan analisis, evaluasi dan menciptakan. Kemapuan analisis didapat ketika siswa dihadapkan pada suatu permasalahan awal yang harus dicari sebuah solusi sebagai stimulus kegiatan proyek yang akan dikerjakan. Kemampuan evaluasi didapat ketika siswa menyimpulkan dan memberikan penilaian terhadap solusi dari masalah yang diberikan. Selain itu mengevaluasi dilakukan oleh siswa ketika melakukan pengujian dari kegiatan proyek yang dilakukan. Kemampuan menciptakan dapat diperoleh siswa ketika menggeneralisasikan ide dalam suatu produk sebagai hasil dari kegiatan model PjBL.

Proses pembelajaran model PjBL pada dasarnya menuntut siswa aktif untuk mencari secara mandiri. Sejalan dengan Sumarmi (2012) PjBL dapat menciptakan suasana lingkungan belajar yang baik bagi siswa yang mendorong siswa mengkontruksi pengetahuan dan keterampilan secara mandiri. Menurut Johnson (2007) Project based leaming (PjBL) mampu menghubungkan muatan akademik dengan konteks dunia nyata, dalam hal ini proyek dapat 
membangkitkan antusiasme para siswa untuk turut berpartisipasi dalam kegiatan pembelajaran. Sehingga dapat disimpulkan bahwa penerapan model PjBL dapat menimbulkan ketertarikan akan belajar secara aktif dan mandiri selain itu siswa dapat mengasah keterampilan dengan membuat suatu produk hasil dari kegiatan proyek. Hal tersebut dapat dibuktikan dengan nilai rata-rata kemampuan berpikir tingkat tinggi siswa yang menerapkan model PjBL lebih tinggi dibandingkan dengan pembelajaran konvensional.

\section{Pengaruh Motivasi Berprestasi Terhadap Kemampuan Berpikir Tingkat Tinggi Siswa}

Berdasarkan hasil analisis data tentang pengaruh motivasi berprestasi terhadap kemampuan berpikir tingkat tinggi siswa dapat diketahui bahwa terdapat pengaruh yang signifikan dari motivasi berprestasi terhadap kemampuan berpikir tingkat tinggi siswa. Hal ini sejalan dengan penelitian yang dilakukan Pamuja (2017), yang menyatakan bahwa kemampuan berpikir tingkat tinggi siswa SMA Negeri 1 Lamongan yang memiliki motivasi berprestasi tinggi lebih baik dari pada siswa SMA Negeri 1 Lamongan yang memiliki motivasi berprestasi rendah. Selain itu didukung oleh penelitian lain yang dilakukan oleh Joko (2017) bahwa hasil belajar ranah kognitif, afektif, dan psikomotor siswa yang memiliki motivasi berprestasi tinggi lebih tinggi signifikansinya dibandingkan dengan siswa motivasi berprestasi rendah.

Motivasi berprestasi diartikan sebagai tenaga dalam diri manusia yang akan mendorong seseorang untuk mencapai prestasi sesuai dengan standar yang telah ditetapkan. Motivasi berprestasi merupakan kebutuhan untuk melakukan dengan baik atau berjuang untuk sukses, dan dibuktikan dengan ketekunan dan usaha dalam mengadapi kesulitan, motivasi berprestasi dianggap sebagai motivasi yang berasal dari dalam diri manusia (Singh, 2011). Menurut Pamuja (2017) motivasi berprestasi dapat menjadi faktor psikologis yang berfungsi mendasari, menimbulkan, dan mengarah dalam menghadapi masalah atau ketika dalam belajar, dalam artian ketika dalam pembelajaran siswa dengan motivasi berprestasi tinggi akan selalu berusaha tampak gigih, serta giat dalam belajar, dan sebaliknya siswa dengan motivasi berprestasi rendah, tampak acuh tak acuh, mudah putus asa serta perhatiannya kurang dalam pembelajaran.

Motivasi menjadikan seseorang berusaha meningkatkan hasil kerja yang ingin dicapai (Sujarwo, 2011). Jika siswa memiliki motivasi berprestasi yang tinggi, siswa tersebut akan mempunyai keinginan yang tinggi pula untuk berprestasi, sehingga akan mendorong dirinya dalam mencapai kesuksesan dan menghindari kegagalan. Pernyataan tersebut sejalan dengan hasil penelitian yang dilakukan (Dwiyanto et. al, (2017), menunjukkan bahwa motivasi berprestasi berperan penting dalam peningkatan kemampuan berpikir kritis siswa, motivasi yang lebih tinggi mengarah pada kemampuan berpikir kritis yang lebih baik dan sebaliknya, semakin rendah motivasi berprestasi mengarah pada kemampuan berpikir kritis yang kurang.

Motivasi berprestasi siswa berpengaruh dalam kegiatan belajar dengan kemampuan berpikir tingkat tinggi. Siswa dengan motivasi berprestasi tinggi akan terlihat antusias mengikuti pembelajaran yang diberikan oleh guru yang melatih siswa dalam kemampuan berpikir tingkat tinggi. Berbeda dengan siswa yang memiliki motivasi berprestasi rendah selama kegiatan pembelajaran akan acuh 
dan kurang antusias sehingga ketika materi pelajaran disampaikan oleh guru atau yang seharusnya dibangun oleh siswa tidak dapat maksimal sehingga ketika mengerjakan posttest cenderung menjawab sebisanya dan menghindari soal yang sulit. Hal tersebut menyebabkan siswa dengan motivasi rendah memiliki nilai yang berbeda.

Pembelajaran yang melatih kemampuan berpikir tingkat tinggi yang diterapkan oleh guru dalam pembelajaran juga dipengaruhi oleh motivasi berprestasi siswa. Siswa dengan motivasi berprestasi tinggi tertarik dengan tantangan yang diberikan oleh guru sehingga mereka akan berusaha untuk mendapatkan nilai yang baik, selain itu juga adanya perasaan bersaing yang tinggi dengan teman lain dalam hal belajar dan berprestasi. Hal ini berbeda dengan siswa yang memiliki tingkat motivasi berprestasi rendah, siswa ini cenderung kurang memiliki perasaan bersaing untuk mencapai hasil yang lebih dari siswa atau teman lain, sehingga hasil yang dicapai kurang maksimal.

Pembelajaran dikelas antara siswa dengan motivasi berprestasi tinggi dan siswa yang memiliki motivasi berprestasi rendah keduanya sama-sama aktif. Namun dapat dibedakan keaktifan mereka dalam kegiatan belajar. Siswa dengan motivasi berprestasi tinggi dapat dilihat dari antusiasme dalam menanggapi pertanyaan dari guru, menyampaikan pendapat, mengajukan pertanyaan dan perhatian ketika kegiatan pembelajaran. Berbeda dengan siswa yang memiliki motivasi rendah mereka aktif dalam kegiatan yang cenderung kurang mendukung mereka dalam melatih kemampuan berpikir tingkat tinggi, sebagai contoh lebih banyak berbicara dengan teman, atau mengganggu teman yang lain dalam belajar. Jadi siswa dengan motivasi berprestasi yang tinggi akan mendorong siswa tersebut untuk memiliki kesadaran dalam belajar secara sungguh-sungguh. Rizkiana (2016) menjelaskan bahwa agar dapat meningkatkan motivasi berprestasi siswa salah satu caranya yakni dengan menggunakan pembelajaran yang inovatif, aktif, dan menantang sehingga siswa tertarik dalam aktivitas belajar. Oleh karena itu motivasi berprestasi hendaknya ditanamkan pada diri siswa, dengan demikian siswa akan dengan senang hati mengikuti proses pembelajaran dan akan tumbuh kemampuan berpikir tingkat tinggi.

\section{Pengaruh Model Project Based Learning (PjBL) Terhadap Kemampuan Berpikir Tingkat Tinggi Ditinjau Dari Motivasi Berprestasi Siswa}

Berdasarkan hasil analisis data tentang pengaruh model project based learning $(\mathrm{PjBL})$ terhadap kemampuan berpikir tingkat tinggi ditinjau dari motivasi berprestasi, diketahui bahwa terdapat pengaruh yang signifikan dari model PjBL terhadap kemampuan berpikir tingkat tinggi ditinjau dari motivasi berprestasi siswa. Penerapan model PjBL dalam penelitian ini secara tidak langsung dapat melatih kemampuan berpikir tingkat tinggi namun tentu didorong juga oleh motivasi berprestasi sebagai faktor internal dalam diri siswa.

Pembelajaran dengan PjBL yang melatih kemampuan berpikir tingkat tinggi tidak akan tercapai dengan maksimal apabila tidak dikung dengan faktor internal dan eksternal. Menurut Azwar (2004) kedua faktor internal dan eksternal dapat mempengaruhi keberhasilan pembelajaran. Dalam penelitian ini yang menjadi faktor internal meliputi kondisi fisik dan psikologis siswa yang tidak lain merupakan tingkat motivasi berprestasi siswa. Faktor eksternal meliputi kondisi sosial, sarana dan prasarana, dan lingkungan belajar siswa, dengan kata lain model 
project based learning (PjBL) merupakan salah satu faktor dari luar yang mempengaruhi pembelajaran.

Project based learning (PjBL) merupakan model yang digunakan dalam penelitian ini. Model PjBL disini mengharuskan siswa aktif dalam memecahkan permasalahan dengan menggagas sebuah ide yang dapat digeneralisasikan menjadi sebuah produk sebagai hasil dari kegiatan proyek. Dalam hal ini siswa dapat melatih kemampuan berpikir tingkat tinggi yang mereka miliki. Namun kegiatan pembelajaran tersebut tidak dapat berjalan dengan maksimal apabila dalam diri siswa tidak ada dorongan untuk belajar dengan sungguh-sungguh. Siswa dengan motivasi berprestasi yang tinggi akan menujukkan sikap mereka yang antusias dan bersungguh-sungguh dalam belajar, sedangkan siswa dengan motivasi berprestasi rendah akan bersikap acuh dan merasa kurang bersemangat mengikuti pembelajaran.

Tujuan pembelajaran dalam penerapan model project based learning (PjBL) harus tercapai. Siswa dengan motivasi berprestasi tinggi akan mudah dalam mencapai tujuan pembelajaran dikarenakan mereka memiliki dorongan dalam diri untuk berlajar dengan sungguh-sungguh. Namun siswa dengan motivasi berprestasi rendah akan sedikit banyak tujuan belajar belum tercapai. Oleh karena itu disni peran guru sangat penting dalam penerapan model $\mathrm{PjBL}$ dalam meltih kemampuan berpikir tingkat tinggi siswa. Pada pembelajaran ini peran guru tidak hanya sebagai fasilitator untuk menyiapkan materi, dan bahan penunjang pembelajaran, tetapi juga perlu bertindak sebagai motivator untuk siswanya terutama siswa yang memiliki motivasi berprestasi yang rendah. Hal tersebut dilakukan agar penerapan model project based learning $(\mathrm{PjBL})$ dapat berjalan sesuai dengan sintaks yang benar sehingga dapat melatih kemampuan berpikir tingkat tinggi siswa dan tujuan belajar dapat tercapai dengan baik.

\section{KESIMPULAN}

Berdasarkan hasil penelitian yang diperoleh dan dibahas pada bab sebelumnya, sehingga diperoleh beberapa hal yang dapat disimpulkan yaitu, (1) ada pengaruh yang signifikan penerapan Model Project Based Learning (PjBL) terhadap Kemampuan Berpikir Tingkat Tinggi Siswa Kelas IV SD, (2) ada pengaruh yang signifikan Motivasi Beprestasi terhadap Kemampuan Berpikir Tingkat Tinggi Siswa Kelas IV SD, dam (3) ada pengaruh yang signifikan penerapan Model Project Based Learning (PjBL) terhadap Kemampuan Berpikir Tingkat Tinggi Siswa ditinjau dari Motivasi Berprestasi Siswa Kelas IV SD.

\section{SARAN}

Berdasarkan hasil penelitian ini, dapat disampaikan saran untuk berbagai pihak yang memiliki hubungan dengan penggunaan hasil penelitian ini, (1) bagi pendidik, khususnya guru sekolah dasar, disarankan menggunakan model project based learning $(\mathrm{PjBL})$ karena dapat melatih siswa dalam kemampuan berpikir tingkat tinggi. Namun perlu diperhatikan bahwa tidak semua materi pelajaran dapat menggunakan model PjBL ini. Selain itu guru juga harus menumbuhkan motivasi berprestasi siswa, agar siswa yang memiliki motivasi berprestasi rendah dapat termotivasi sehingga antusias dalam mengikuti kegiatan pembelajaran, (2) faktor pendukung yang perlu diketahui dalam tercapainya keberhasilan pembelajaran juga perlu diperhatikan. Adapun faktor tersebut antara lain faktor 
internal (tingkat kecerdasan, tingkat emosional, kreativitas, motivasi, bakat, minat dan lain-lain) dan faktor eksternal yang meliputi (kurikulum, lingkungan sosial, sarana-prasarana dan lain-lain).

\section{DAFTAR RUJUKAN}

Amalia, T. 2015. Pengaruh Model Project Based Learning Berbasis IntegrasiInterkoneksi Terhadap Kemampuan Berpikir Tingkat Tinggi Siswa Kelas X MAN Yogyakarta III Pada Materi Suhu dan Kalor. Tesis Tidak Diterbitkan. Yogyakarta: UIN Sunan Kalijaga.

Azwar, S. 2004. Pengantar Psikologi Intelegensi. Yogyakarta: Pustaka Pelajar

Anderson, L.W. \& Krathwohl, D.R. (Eds). 2015. Kerangka landasan untuk pembelajaran, pengajaran, dan asesmen: revisi taksonomi pendidikan Bloom.(Terjemahan Agung Prihantoro). Yogyakarta: Pustaka Pelajar.

Anjarini. 2017. Pengaruh Model Project Based Learning (PJBL) Berbasis Outdoor Study Terhadap Kemampuan Berpikir Kreatif Dan Kemampuan Menyusun Karya Ilmiah Geografi SMA. Tesis Tidak Diterbitkan. Malang: Pascasarjana UM

Deluca. 2011. The GRIDc Project Developing Students's Thinking Skills in a Data-Rich Environment. Journal of Technolofy Education. 23. https://doi.org/10.21061

Dwiyanto, F. Setyosari, P. Wahjoedi, Dwiyogo, W. D. 2017. Effects of Problem Based Learning Stretegy and Achievement Motivation on the Student's Critical Thinkin Abilities. International Journal of Science and Research (IJSR). 6(6).

Fuadah. K. 2017. Pengembangan Pembelajaran Biologi Berbasis Project Based Learning Bersumber Potensi Lingkungan Lokasl Untuk Meningkatkan Pemahaman Konsep, Keterampilan Ilmiah, Dan Sikap Ilmiah Siswa SMA Kanjeng Sepuh Sidayu Gresik. Tesis Tidak Diterbitkan. Malang: Pascasarjana UM.

Greenstein, A. 2012. Assesing 21 st Century Skill, A Guide To Evaluating Mastery and Authentic Learning. USA. Corwin A Sage Company.

Hayati. 2016. Effektivitas Student Worksheet Berbasis Project Based Learning Dalam Menumbuhkan Kemampuan Berpikir Kritis Siswa Pada Mata Pelajaran Geografi. Jurnal Pendidikan, 1(3): 468-474.

Hosnan. 2014. Pendekatan Saintifik dan Konstektual dalam Pembelajaran Abad 21, Bogor: Ghalia Indonesia.

Johnson, E.B. 2008. Contextual Teaching \& Learning: Menjadikan Kegiatan Belajar-Mengajar Mengasyikkan dan Bermakna. Bandung: MLC.

Joko. 2017. Pengaruh Model Pembelajaran Berbasis Proyek, Motivasi Belajar, Dan Lokus Kendali Terhadap Hasil Belajar. Disertasi Tidak Diterbitkan. Malang: Universitas Negeri Malang.

Kamin, \& Chinedu. 2015. Strategies For Improving Higher Order Thinking Skills In Teaching And Learning Of Design And Technology Education. Malaysia: Universiti Teknologi Malaysia.

Kizkapan, O \& Bektas, O. 2017. The Effect of Project Based Learning on Seventh Grade Students Academic Achievement. International Journal of Instruction. 10(1): 37-54. http://doi.org/10.12973/iji.2017.101 
Lopes, M.P. Macendo. J. 2014. Project Based Learning to Promote High Order Thinking and Problem Solving Skills in Geotechnical Course. International Journal Engineering Pedagogy, 4(5). www.ijep.org

Maula. 2014. Pengaruh PjBL (Project Based Learning) terhadap Kemampuan Berpikir Kreatif dan Hasil Belajar Siswa pada Materi Pengelolaan Lingkungan. (online). Diakses tanggal 7 Oktober 2017.

Noor, A. M. 2009. Pedagogical Issues in integrating Thinking Skills in The Classroom. International Journal for Education Studies, 2(1): 55-68. DOI:10.26822/iejee.2018336189.

Pamuja, I. A. 2017. Pengaruh Model Pembelajaran Inkuiri Terbimbing dan Motivasi Berprestasi Terhadap Kemampuan Berpikir Tingkat Tinggi. Malang: Universitas Negeri Malang. Tesis Tidak Diterbitkan.

Rizkiana, F., Dasna, I.W., \& Marfu'ah, S. 2016. Pengaruh Praktikum Dan Demonstrasi Dalam Pembelajaran Inkuiri Terbimbing Terhadap Motivasi Berprestasi Belajar Siswa Pada Materi Asam Basa Ditinjau Dari Kemampuan Awal. Jurnal Pendidikan Universitas Negeri Malang. 1(3): $354-362$

Sani, R. 2014. Pembelajaran Saintifik untuk Implementasi Kurikulum 2013. Jakarta: Bumi Aksara.

Sanderayanti, D. 2015. Penaruh Motivasi Berprestasi Dan Kemampuan Berpikir Kritis Terhadap Hasil Belajar Matematika Siswa Di SDN Kota Depok. Jurnal Pendidikan Dasar. Universitas Negeri Jakarta. Volume 6 Edisi 2 Desember 2015.

Singh. 2011. Study of Achievement Motivation in Relation to Academic Achievement of Student. International Journal of Educational Planning \& Administration, 1(2): 161-171.

Setyorini, I. Y. Subandi, Santoso, A. 2015. Motivasi Dan Kemampuan Berpikir Tinkat Tingi Siswa Setelah Pembelajaran Kimia Dengan Strategi Inkuiri Terbimbing. Jurnal Ilmu Pendidikan Universitas Negeri Malang. 21(2): 151-159.

Sujarwo. 2011. Pengaruh Strategi Pembelajaran (Inkuiri Terbimbing dan Ekspositori) Terhadap Hasil Belajar Sosiologi pada Siswa SMA Yang Memiliki Tingkat Motivasi Berprestasi dan Kreativitas Berbeda. Disertasi Tidak Diterbitkan Malang: Pascasarjana UM

Sumarmi. 2012. Model-model Pembelajaran Geografi. Yogyakarta: Aditya Media Susanto. A. 2013. Teori Belajar dan Pembelajaran di Sekolah Dasar. Jakarta: Prenada Media Group

Tembang, Y. Sulton, \& Suharjo. 2017. Peningkatan Motivasi Dan Hasil Belajar Melalui Model Pembelajaran Think Pair Share Berbantuan Media Gambar Di Sekolah Dasar. Jurnal Pendidikan Universitas Negeri Malang. 2(6): 812-817.

The George Lucas Educational Foundation. 2005. Instructional Module Project Based Learning. (Online), http://www.edutopia.org/modules/PBL/ whatpbl.php. Diakses tanggal 8 Oktober 2017.

Yusmanto, H. 2017. Meningkatkan Higher Order Thinking Skills (HOTS) Dan Hasil Belajar IPS Melalui Penerapan Model Pembelajaran Kooperatif Corousel Feedback Dan Round Table (Studi Pada SMPS Islam Terpadu 
Darul Azhar Kabupaten Aceh Tenggara). Tesis Tidak Diterbitkan. Malang: Pascasarjana UM.

Zehrihun, Z. Beisshunzein, J \& Van Os, W. 2012. Student Learning Experience as Indicator of Teachin Quality. Educational Assessment, Evaluastion and Accountability, 24. http://dx.doi.org/10.1787/19939019

Zubaidah. 2017. Keterampilan Abad ke-21 Keterampilan Yang Diajarkan Melalui Pembelajaran. Prosiding. Malang: Jurusan Biologi FMIPA Universitas Negeri Malang. 